\title{
İş Yaşam Dengesinin Örgütsel Bağlılık ve Çalışan Memnuniyetine Etkisi
}

\author{
The Effect of Work- Life Balance on Employee Satisfaction and Organizational \\ Commitment
}

Oya KORKMAZ1 ${ }^{1}$ Evrim ERDOĞAN²

\begin{abstract}
ÖZET
Bilgi iletişim teknolojisinde ve bireylerin yaşam tarzlarında meydana gelen hızlı gelişmeler nedeniyle çalışanların iş ve kişisel yaşamları arasında bir denge kuramadıkları ve bu sorunu gidermek içinse örgütlerin iş yaşam denge programlarını uygulamaya koydukları görülmektedir. İçsel pazarlama yaklaşımına göre dış müşterilerin memnun edilebilmesi, iç müşteriler olan çalışanların da memnun edilebilmesine bağlıdır. Çalışanların iş ve özel yaşamları arasında denge kurabilmeleri örgüte olan bağlılıklarını dolayısıyla memnuniyetlerini etkilemektedir. Bu nedenle bu kavramlar arasındaki ilişkileri ortaya koymak yöneticilerin örgütün insan kaynağını iyi yönetmesi ve çeşitli insan kaynağı politikaları üretmesi açısından son derece önem taşımaktadır. $\mathrm{Bu}$ açıdan bakıldığında bu çalışmanın; iş yaşam dengesinin, örgütsel bağlılık ve çalışan memnuniyeti ile olan ilişkisini aynı zamanda örgütsel bağlıığın da çalışan memnuniyetine olan etkisini yapısal eşitlik modeli yardımıyla ortaya koyması amaçlanmaktadır. Bu amaçla bu çalışma Türkiye Taş Kömürü Kurumu Genel Müdürlüğü'nde çalışan beyaz yakalı çalışanlar üzerinde yapılmış ve çalışmanın sonucunda iş yaşam dengesinin örgütsel bağlıığı arttırdığı, doğrudan çalışan memnuniyeti üzerinde anlamlı bir etkisinin olmadığı ancak örgütsel bağlıı̆̆ın çalışan memnuniyetini arttırdığı tespit edilmiştir.
\end{abstract}

Anahtar Kelimeler: İş-yaşam dengesi, örgütsel bağlılık, çalışan memnuniyeti, yapısal eşitlik modeli.

\section{GíRiş}

İş yaşam dengesi; bugünün iş dünyasında üzerinde çalışılması gereken önemli bir konu olarak görülmektedir. Çünkü iş yaşam dengesi çalışanın yaşamında ve davranışlarında önemli sonuçlara yol açmaktadır. Çalışma saatlerinin düzensizliği, vardiyalı çalışma sistemi, rol belirsizliği, rol çatışması, iş güvenliğinin olmayışı, aşırı ya da az iş yükü, ücretin yetersiz olmaSı, çalışma ortamından kaynaklanan fiziksel etmenler gibi çok sayıda faktör çalışanlar üzerinde olumsuz etkiye neden olmakta ve onların sağlıklarını tehdit etmektedir (Kılıç ve Sakallı, 2013: 210). Ayrıca iş yaşam dengesizliği, mesleki yaralanma ve kaza riskinin artmasına, bireylerin sağlığının bozulmasına ve bireyle-

\begin{abstract}
Due to the rapid developments and changes in the information and communication technologies, and also, in life styles of people, it has been observed that employees can not make a balance between work and personal lives; and therefore in order to cope with this problem organizations have practiced work-life-balance programs. According to the internal marketing approach, to be satisfied of external customers depends on to be satisfied of personnel who are internal customers. If the employers achieve to establish a balance between work and personal lives that would affects their satisfaction and organizational commitments as well. Thus, in order to specify correlations between these concepts is extremely significant in terms of being able to produce various politics related with human resources and managers to better manage the organization's human resources. In relation to this concept, this study is aimed to explain the correlation between the organizational commitment and employee satisfaction of the worklife balance as well as the effect of the organizational commitment on employee satisfaction by means of structural equation model. For these purposes, in this study, the questionnaire was applied to the white-collar employees working at Turkish Hardcoal Enterprise (TTK) and at the end of this study, it has been found out that there has been a considerable increase in organizational commitment as a result of the work-life balance and that the work-life balance has not been founded a direct and meaningful effect on the employee satisfaction. However, that the organizational commitment has increased the employee satisfaction has been identified.
\end{abstract}

Keywords: Work-life balance, organizational commitment, employee satisfaction, structural equation modeling.

rin sosyal yaşam için ayırdıkları zamanın azalmasına da neden olmaktadır (Wirtz vd., 2011: 362). Bütün bu nedenler işverenleri örgütlerinde iş yaşam dengesini kurmaya zorlamaktadır.

Objektif anlamda iş yaşam dengesi; sağlık, kariyer ve özel yaşamda başarı olarak nitelendirilirken, sübjektif anlamda; iş ve kişisel yaşam alanında memnuniyet olarak nitelendirilmektedir (Hilderbrandt, 2006: 255-256). Çalışanların kişisel ve iş yaşamlarındaki memnuniyeti örgütleri de olumlu yönde etkilemektedir. Çalışanların kendilerini yetiştirebilmek için intiyaç duydukları zamana sahip olmaları, kalite ve becerilerini arttırmakta bu da doğrudan verimlilik artışıla sonuçlanmaktadır. Örgütlerin kişisel yaşamın devamlılı-

\footnotetext{
${ }^{1}$ Yrd. Doç. Dr., Mersin Üniversitesi, Tarsus Uygulamalı Teknoloji ve İşletmecilik Yüksekokulu, oyakorkmaz@yahoo.com

${ }^{2}$ Yrd. Doç. Dr., Ondokuz Mayıs Üniversitesi, İktisadi ve İdari Bilimler Fakültesi, İşletme Bölümü, evrim.erdogan@omu.edu.tr 541
} 
ğını destekleyici politika ve uygulamaları çalışanların iş ve örgüte bağlılığını arttırmakta, devamsızlığı azaltmakta, verimlilik ve üretkenliğin artmasına neden olmaktadır. Bireylerin iş yaşam dengesini oluştururken dikkat ettikleri bir başka nokta ise çalışma yaşamı sonrasındaki hayatlarında, kişisel memnuniyetin sağlanması için şimdiden iş dışı aktivitelerle ilgilenmek istemeleridir. Bu da ancak çalışanın iş ve kişisel yaşamı arasında denge kurmasıyla mümkün olabilecektir (Doğrul ve Tekeli, 2010: 13).

İş yaşam dengesi son 10 yıldır insan kaynakları yönetiminin dikkatini çekmeye başlamış önemli bir kavramdır. Bu kavram, bir kişinin işi ile yaşamı arasındaki sorumlulukları üzerindeki kontrolünü ifade etmektedir. Örgütler son zamanlarda iş yaşam dengesi hakkında daha fazla bilinçlenmiş ve arkadaşça çalışma yaşam politikalarını önermişlerdir. İş yaşam dengesi çalışanın istediği, yöneticilerin ihtiyaç duyduğu ve örgütün ise göz ardı edemediği bir kavramdır. Başarılı bir iş yaşam dengesi stratejileri çalışanların stres seviyesini azaltmakta, sağlık harcamalarının maliyetini düşürmekte ve örgütün kar elde etmesini sağlamaktadır. Bunun yanı sıra iş yaşam dengesi birtakım faktörlerden de etkilenmektedir. Bu faktörler; aileyi, örgütü, toplumu, hükümeti, kanunları ve çalışanları kapsamaktadır (Thulasimani, Duraisamy ve Rathinasabapathi, 2010: 446).

İş yaşam dengesi örgütün başarısında önemli bir rol oynamaktadır. Bir örgütün en büyük zenginliği insan kaynağı olup onların mutluluğu ve refahı örgüte pozitif sonuçlar kazandırmaktadır. Bahsedilen bu pozitif sonuçlar bireysel ve örgütsel olmak üzere ikiye ayrılmaktadır. Bireysel sonuçlar; iş ve iş ortamı dışında ilişkileri geliştirme ve daha iyi çalışma koşulları şeklinde kendini gösterirken, örgütsel sonuçlar; bireyin verimliliğinde, sorumluluğunda ve bağlılığında artış, daha iyi takım çalışması, daha iyi iletişim ve çalışanın moralinde artış şeklinde kendini göstermektedir. Ayrıca örgütler iş yaşam dengesinin kurulmasına yardımcı olacak birtakım stratejiler geliştirmişlerdir. Bu stratejiler; iyi bir zaman yönetimini, hafta sonlarını dinlenerek geçirmeyi, faaliyetleri planlamayı ve önyargılardan kurtulmayı içermektedir (Thulasimani, Duraisamy ve Rathinasabapathi, 2010: 448).

İ̧ yaşam dengesi, çalışanın kendini iyi hissetmesi için zekice tasarlanmış bir stratejik insan kaynağı yönetim aracıdır. İ̧ yaşam dengesi, iş ile iş dışı yaşam arasındaki ilişkiyi inceleyen bir kavramdır. Bugün farklı sanayi kollarında faaliyet gösteren birçok örgütte ve bu örgütlerde çalışan kişilerce bu kavramın farkına varılmış ve uygulanmaya konulmuştur. İş yaşam dengesi çalışanın kendini fiziksel ve duygusal açıdan iyi hissetmesini sağlayan stratejik bir insan kaynağı yönetim aracıdır (Wong ve Ko, 2009: 195).
İş yaşam dengesi örgütlerin pozitif iş çevresi yaratmasına yardımcı olmakta, aynı zamanda çalışanın örgütte uzun süre kalmasını sağlayarak eğitim yatırımlarının geri dönüş oranını artırmaktadır. Kişinin kariyer talebi ile yaşam sorumluluklar arasındaki dengeyi ifade eden iş yaşam dengesi bir örgütte çalışan çeşitliliğini artırmakta ve çalışanın işe olan adaptasyonunu kolaylaştırmaktadır. Ayrıca iş yaşam dengesi yöneticilerin liderlik yeteneğini geliştirmekte ve çalışanların gereksinimi için çeşitli stratejiler üretmektedir (Cieri, Holmes, Abbott ve Pettit, 2002:3).

İçsel pazarlama yaklaşımına göre çalışanlar müşteri olarak kabul edilmektedir. İç müşteri olan çalışanların istek ve ihtiyaçlarını karşılamak yani memnun çalışanlar yaratmak; çalışan devir hızının azaltılmasına, işyeri uyumunun gerçekleşmesine ve üretimde kalitenin artmasına neden olmaktadır. Bu nedenle bugün birçok örgüt yetenekli çalışanı örgüte kazandırmak, elde tutmak, tükenmişliği azaltmak ve iş yerinin cazibesini artırmak amacıyla iş yaşam kalitesini geliştirmede aktif rol oynamaktadır (McGraw ve Heidtman, 2009).

İnsan kaynağının etkin yönetimine ilişkin etkili yaklaşımlardan biri olan iş yaşam dengesi yukarıda bahsedilen yararlarından dolayı bu çalışmada incelenmeye değer görülmüş ve bu çalışmanın; iş aile yaşamı etkileşiminde, çalışan bireyler ile aile üyeleri arasındaki dengenin kurulabilmesine yardımcı olması beklenilmiştir. Kurulacak olan böyle bir denge çalışanlar için olduğu kadar, çalışanların içinde bulunduğu örgüt ve hatta toplum için de birçok fayda sağlayacaktır. Bu faydalar örgütsel bağlılık ve çalışan memnuniyeti şeklinde kendini gösterecektir. Bu çaısşma, insan kaynağını etkin bir şekilde yönetmek için birbirleri ile ilişkili olduğu düşünülen bu kavramlardan yöneticilerin faydalanmasını ve yöneticilerin gelecekte çalışan verimliliğini arttırıı insan kaynağı politikaları üretip geliştirmelerine yardımcı olmayı hedeflemektedir. Ayrıca bu çalışma yeni nesil iş gücü için cazip olmak isteyen işverenlere yeni nesil insan kaynakları politikalarını oluştururken nelere dikkat etmeleri gerektiği konusunda yol göstermektedir. Bu çalışma, iş yaşam dengesinin; çalışan memnuniyeti ve örgütsel bağlılıkla olan ilişkisini ve örgütsel bağlılığın da çalışan memnuniyetiyle olan etkisini yapısal eşitlik modeli yardımıyla ortaya koyması açısından diğer çalışmalardan farklılaşmaktadır. Böylece bu çalışma yönetim organizasyon yazınında var olan bir eksikliği gidermekte ve literatüre büyük katkı sağlamaktadır. Ayrıca bu çalışma, iş yaşam dengesinin; örgütsel bağlılığı arttırdığı ve doğrudan çalışan memnuniyeti üzerinde anlamlı bir etkisinin olmadığı ancak örgütsel bağlıı̆̆ın çalışan memnuniyetini art- 
tırdığı şeklindeki ilişkiyi ortaya koyması açısından da diğer çalışmalardan farklılaşmaktadır. Araştırmanın sonucunda elde edilen bu bulguların yönetim organizasyon yazınına büyük katkı sağlayacağı düşünülmektedir. Bütün bunların yanısıra rekabetin bir gereği olarak kaliteli iş gücünü örgütte tutabilmek, mutlu çalışan ve yöneticiler yaratabilmek için bu çalışmanın yapılmasına ihtiyaç duyulmuştur. Böyle bir çalışmada varılmak istenen nokta çalışanların iş yaşam çatışmalarını azaltmak ve yaşam kalitelerini artırmaktır. Bu çaIışmada, araştırma modeli gereği olarak iş yaşam dengesi, örgütsel bağlılık ve çalışan memnuniyeti olmak üzere üç ayrı ölçekten faydalanılmıştır. Guest (2001) yayınladığı bir çalışmasında iş yaşam dengesinin; iş ve aile dengesi olmak üzere iki boyutu olduğunu belirtmiştir. Bu nedenle iş yaşam dengesi ölçeği iş ve aile dengesi olmak üzere iki boyutta incelenmiştir. Bu ölçekler Zonguldak ilinde faaliyet gösteren TTK Genel Müdürlüğü'nde çalışan beyaz yakalı çalışanlara uygulanmıştır. Elde edilen veriler yapısal eşitlik modeli yardımıyla çözümlenerek araştırma hipotezlerinin doğruluğu sınanmıştır. Yapısal eşitlik modeli sonuçlarına göre; iş yaşam dengesinin örgütsel bağlılığı, örgütsel bağlılığın ise çalışan memnuniyetini anlamlı olarak etkilediği ancak iş yaşam dengesinin doğrudan çalışan memnuniyetine anlamlı bir etkisinin olmadığı tespit edilmiştir. Çalışmamız; giriş, kuramsal çerçeve, araştırmanın metodolojisi, sonuç ve değerlendirme olmak üzere dört bölümden oluşmaktadır. Birinci bölümde araştırma için kuramsal bir çerçeve sunulmuş ve bu araştırmanın diğer araştırmalarla nasıl ilişkili olduğu ortaya konmuştur. İkinci bölümde ise iş yaşam dengesi, örgütsel bağlılık ve çalışan memnuniyeti ile ilgili kavramlar hakkında teorik bilgi verilmiştir. Üçüncü bölümde araştırmanın metodolojisi olarak araştır- manın amacına, yöntemine, kullanılan ölçeğe, modele, örnekleme ve bulgulara yer verilmiştir. Dördüncü bölümde ise araştırma sonucu elde edilen bulgular daha önce yapılmış çalışmalar ışığında değerlendirmeye tabi tutulmuştur.

\section{KURAMSAL ÇERÇEVE}

\section{1. İ̧ Yaşam Dengesi}

Günümüzde örgüte rekabet avantajı kazandıran en önemli konuların başında iş yaşam dengesi gelmektedir. İş yaşam dengesi insan kaynakları bölümünün örgüte rekabet avantajı kazandırmak için geliştirdiği ve üzerinde çalıştığı yeni bir çalışma alanını oluşturmaktadır. İ̧ yaşam dengesi uygulamaları insan kaynakları yönetimi açısından, çalışanı örgütte tutma stratejilerinden birini oluşturmaktadır. İş yaşam dengesi çalışanların moralini, bağlılığını ve iş doyumunu gözeten, işyerindeki sorunları ve stres yaratan faktörleri azaltan, örgütlerin yetenekli ve değerli çalışanlarını işe alma ve onları kaybetmeme konusundaki becerilerini geliştiren önemli bir faktör olarak görülmektedir (Küçükusta, 2007: 244).

İş yaşam dengesi küresel rekabetin ve işgücünün zaman içerisinde gelişimi sonucu ortaya çıkmış yeni bir kavramdır. İş yaşam dengesi için yapılan programların başlangıcı 1930'lara dayanmakla beraber ilk kez 1986 yılında ortaya çıkmış yeni bir kavramdır. 2. Dünya Savaşı'ndan önce, W.K.Kellog adında bir şirket ilk kez, üç adet sekiz saatlik vardiya sistemi yerine dört adet altı saatlik vardiya sistemini geliştirerek çalışanın moralinin ve etkinliğinin artmasını sağlamıştır. Önceki yıllarda iş aile dengesi olarak kullanılan bu kavram günümüzde iş yaşam dengesi olarak kullanılmaya başlamıştır (Lockwood, 2003: 2). İş yaşam dengesinin bu süreçte geçirdiği evreler Tablo 1'de verilmiştir.

Tablo 1: İ̧ Yaşam Dengesinin Geçirdiği Evreler

\begin{tabular}{|l|l|}
\hline Zaman Periyodu & İş Yaşam Dengesindeki Değişimler \\
\hline Toplumsal yaşamın ilk yılları & Yaşamak için çalışmak \\
\hline Sanayi devriminden önce & Aile yaşamı ile iş yerinin ayrımı \\
\hline Sanayi devrimi 1800'lerin ortası & İş yeri ile aile yaşamının birbirinden ayrılarak erkeklerin iş hayatında baskın hale gelmesi \\
\hline 18. yüzyılın sonu ile 19. yüzyılın başı & İş ve ailenin ayrımı \\
\hline $\begin{array}{l}\text { 19. yüzyılın başı ile 1950 arası dönem } \\
\text { 1950'li yıllar ile 1980'lerin başı arasındaki } \\
\text { dönem }\end{array}$ & $\begin{array}{l}\text { İnsan gücünün teknolojiye bağlı olması ve kadının işyerinde baskın hale gelmesi teknoloji nedeniyle tersine çevriliyor ve iş yaşam dengesi olanakları } \\
\text { tanımlanıyor }\end{array}$ \\
\hline $\begin{array}{l}\text { 1980'ler ile 2008 arası dönem } \\
\text { Büresel işgücü içerisinde daha çok anne konumundaki durgunluk- } 2008 \text { ve daha } \\
\text { sonraki dönem }\end{array}$ & $\begin{array}{l}\text { İş ve aileyle ilgili çatışmalarda artış ve bu duruma bağ bülı olarak iş yaşam dengesimas } \\
\text { olanaklarında azalma görülmesi }\end{array}$ \\
\hline
\end{tabular}

(Kaynak: Naithani, Pranav, 2010:154.) 
Tablo 1'de yer alan iş yaşam dengesine ait değişimler iş yaşam dengesi kavramının sanayi devrimi ile başladığına dikkat çekmektedir. Sanayi devriminden önce üretim aileler tarafından kendi tüketimleri için yapılırken sanayi devrimiyle başlayan süreçte, işyerleri, ev ve aileden uzaklaşmış ve üretim bunların dışındaki örgütlerde gerçekleştirilmeye başlamıştır. Önceleri bireylerin iş ve aile konumlarında farklılık yokken, iş ve aile aktiviteleri endüstri devriminden sonra farklı yerlerde, farklı zamanlarda, farklı insan gruplarıla ve farklı davranış kurallarıyla gerçekleştirilir olmuştur. İş ve aile, endüstrileşmeyle birlikte zaman ve mekan olarak birbirinden farklılaşmış olsa da, aralarında sıkı yapısal ilişkiler ve güçlü bir etkileşim olan iki önemli sosyal alt sistem olarak varlıklarını devam ettirdikleri görülmüştür. Son yıllarda sanayi sonrasına geçiş sürecinde ekonomik, sosyal ve kültürel alanda yaşanan köklü değişimler çalışma yaşamı açısından da, yeni oluşumları ve yaklaşımları beraberinde getirmiştir (Kapız, 2002: 139). Bu yeni oluşumlardan birisi de kadınların iş yaşamına girmesidir. İş yaşamına giren kadınların evdeki rollerinden dolayı erkeklere göre iş yaşam dengesini kurmakta daha fazla zorlandıkları görülmektedir (Clutterbuck, 2003). Bu nedenle, iş ve aile yaşam alanları etkileşiminin boyutlarının değiştiği ve iş ile aile yaşamı dengesini sağlayabilmenin öneminin giderek arttığı görülmektedir (Kapız, 2002: 139). İş aile dengesini sağlayabilmenin öneminin giderek artması nedeniyle örgütler iş yaşam denge programlarını uygulamaya koymuş ve iş yaşam denge programlarını uygulayan örgütlerin insan kaynağı pazarını ellerinde tuttukları ve insan kaynağı açısından rekabet avantajı kazandıkları tespit edilmiştir (Clutterbuck, 2003).

1950'lerle bu yüzyılın başları arasında gerek işveren, gerekse çalışan açısından getirdiği faydalar nedeniyle iş yaşam dengesi araştırmalarında büyük artışlar yaşanmış ve iş yaşam denge programları örgütsel seviyede uygulanmaya başlamıştır. İş yaşam dengesinin getirdiği faydalar sadece sosyal ve psikolojik boyutla sınırlı kalmamış, aynı zamanda ekonomik anlamda da yarar sağlamıştır. İş yaşam dengesi, örgütün imajını artırmakta ve çalışanların kalitesini geliştirmektedir. Ayrıca iş yaşam dengesini etkin bir şekilde uygulayan örgütlerin daha yüksek pazar payına sahip oldukları ve daha iyi finansal performans gösterdikleri de tespit edilmiştir (Naithani, 2010: 151).

İş yaşam dengesi; iş yaşamı ile kişisel yaşam arasındaki rekabetin en aza indirgenmesine dayanmaktadır. İş yaşam dengesi, yöneticileri esnek çalışma saatleri ve iş paylaşımı konusunda cesaretlendirmektedir. Esnek çalışma saatlerinin ve iş paylaşımının örgüte sağladığı birtakım yararlar bulunmaktadır. Bu yararlar; istihdamı artırmak, çalışanı elde tutmak, çaIışan memnuniyetini sağlamak ve verimliliği artırmak şeklinde sıralanabilmektedir. Ayrıca iş yaşam dengesinin bahsedilen bu yararları yanında maliyet etkinliğini sağlamak ve performansı artırmak gibi pozitif etkilerinin de bulunduğu saplanmıştır (Manfredi ve Holliday, 2004: 6).

İş yaşam dengesi; aile, özel ve çalışma yaşamı arasındaki uyumu ifade etmektedir. İş yaşam dengesi aslında yaşamın farklı bölümleri arasındaki dengeyi ifade etmektedir (Tucholka ve Weese, 2007: 5). İş çevresinde yaşanan rekabet baskısı ekonomik, sosyal ve kültürel alanda yaşanan köklü değişimlere paralel olarak her geçen gün artmaktadır. İş çevresinde yaşanan bu rekabet baskısı bireysel birtakım problemlere yol açmaktadır. Bu problemlerden biri de iş ile yaşam arasındaki dengenin kurulamamasından kaynaklanmaktadır (Narayanan ve Narayanan, 2012).

İş yaşam dengesi; bireyin farklı talepleri ile zaman ve enerji arasındaki gerçek ya da potansiyel çekişmeyi yönetme becerisini ya da bireyin intiyaçlarının memnun edici düzeyde karşılanmasını ifade etmektedir (Clutterbuck, 2003). İş yaşam dengesi örgüt içerisinde pozitif bir kültür yaratmaktadır. İş yaşam dengesinin örgütte yarattığı pozitif kültürün meydana geliş sırası Şekil 1'de görülmektedir.

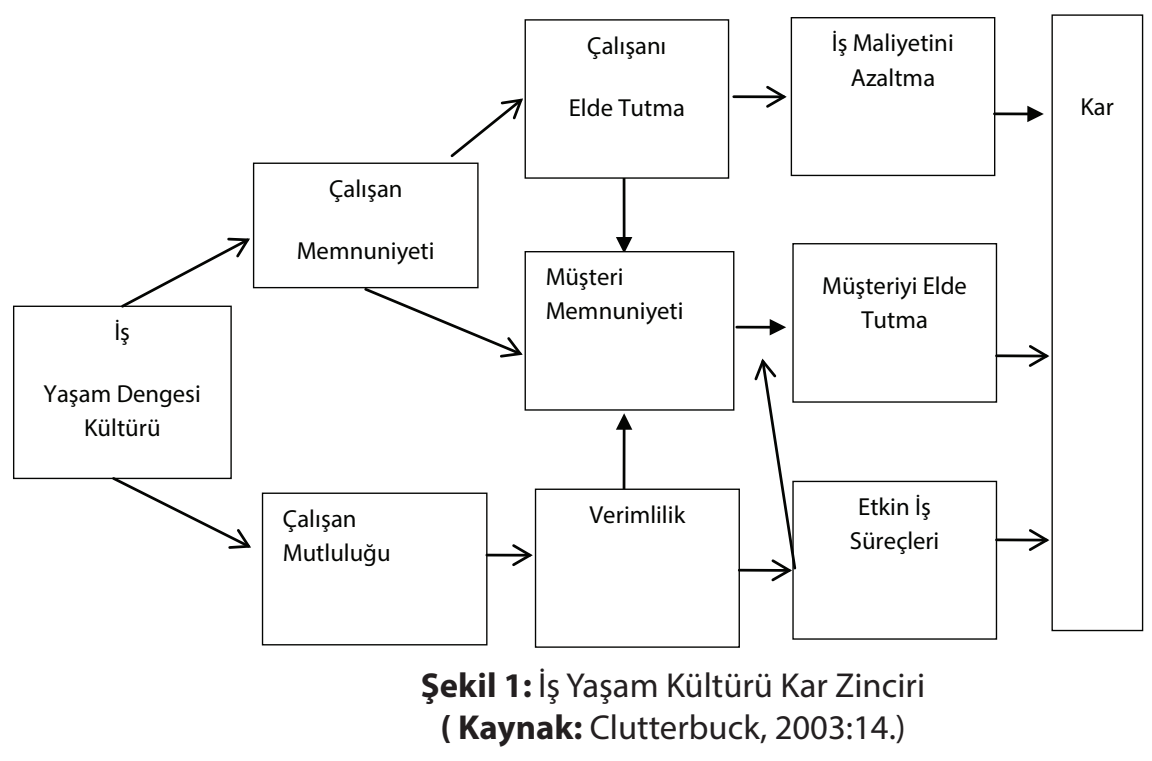


Şekil 1'de de görüldüğü üzere çalışan memnuniyeti iş yaşam dengesiyle orantılı olarak değişmekte ve bu kavram daha geniş ele alındığında örgüt performansını olumlu yönde etkilediği görülmektedir. Ayrıca iş yaşam kültürü kar zincirine baktığımızda iş yaşam dengesinin çalışanı örgütte tutacak en güçlü araç olduğu görülmektedir.

İş yaşam dengesi (esnek çalışma saatleri, iş paylaşımı, sağlık olanakları, bilgisayar bağlantısı aracıllğıyla iletişim kurarak insanların evlerinde çalışması) örgüte rekabet avantajı kazandırdığından dolayı son zamanlarda popüler hale gelmiş bir kavramdır. Bu nedenle birçok örgütler iş yaşam dengesini örgütlerinde kurmak için aktif rol almaya başlamışlardır. İş yaşam dengesi işveren, yönetici ve çalışanlar için mesleki ve bireysel amaçlara ulaşmada önemli bir araç olarak görülmektedir. İş yaşam dengesini bir örgütte tesis edebilmek için güçlü bir yönetim desteğine ihtiyaç duyulmaktadır. İş yaşam dengesi faaliyetlerinin örgütün temel iç amaçlarına örneğin; farklılığa, eşit fırsatlara ve daha geniş toplumsal amaçlara katkı sağladığı görülmektedir. Ayrıca iş yaşam dengesinin, çalışan motivasyonu üzerinde anlamlı bir etki yarattığı ve örgütün değerini artırdığı da görülmektedir (Clutterbuck, 2003).

İş yaşam dengesi çalışanın işi ile kişisel yaşamının uzlaşmasını, aslında işi ile kişisel talebinin yönetimini ifade etmektedir (Darcy vd., 2012: 112). İ̧̧ yaşam dengesi gerek çalışanlar, gerekse yöneticiler açısından iş algısını değiştirmiş ve örgüte birtakım üstünlükler kazandırmıştır (Maxwell, 2005: 181). İş yaşam dengesi örgütsel ve bireysel yaklaşım olmak üzere iki boyut içermektedir. Bu iki boyut, iş yaşam stratejisinin iki bacağını oluşturmaktadır. Bu bacaklardan biri olan örgütsel yaklaşım, sistem yaklaşımı (sol bacak) olarak adlandırımakta ve örgüt çalışanlarının daha iyi iş yaşam dengesi kurmasına yardımcı olmaktadır. Bireysel yaklaşım olan sağ bacak ise esnek çalışma saatleri, sağlık sigortası gibi çalışan destek programları tarafından kurulmaktadır. Her çalışan için farklı iş yaşam dengeleri bulunmaktadır. Örneğin kariyerinin başında olan bir kişinin kurduğu iş yaşam dengesi ile emekli bir kişinin kurduğu iş yaşam dengesi birbirinden çok farklı olmaktadır. İş yaşam dengesi, bireyin yaşamında denge ve simetriyi ifade ederken aynı zamanda kişinin bütün yaşamı boyunca uyum ve eşgüdüm yaratmasına da katkı sağlamaktadır. Ayrıca iş yaşam dengesi bireyin kişisel ve mesleki yaşamının kalitesini geliştiren iş deneyiminden de etkilenmekte$\operatorname{dir}$ (Tariq, Aslam, Siddique ve Tanveer, 2012: 578-579).

İş yaşam dengesi çalışanın yaşamındaki temel taşlardan birini oluşturmakta ve çalışan ile işveren arasında yakın bir bağ kurmaktadır. İş yaşam dengesi; rekabetçi iş çevresinden gelen dış baskılarla çalışanın boş zamanını ya da ailesiyle geçirdiği zamanı ifade ederken, iç baskılarla ise çalışanın kendi beklentileri ile gerçekçi amaçlarını yönetmeyi ifade etmektedir (Khallash ve Kruse, 2012: 682). İş yaşam dengesi en geniş ifadeyle, çalışanın memnuniyet düzeyini ve kişinin yaşamı içerisinde üstlendiği birçok rolün uyumunu ifade etmektedir. İş yaşam dengesi uygulamalarının en çok çalışan memnuniyeti ve örgütsel bağlılık üzerinde etkisini hissettirdiği görülmektedir (Susi ve Jawaharrani, 2011: 480).

\section{2. Örgütsel Bağlılık}

Örgütsel bağlılık birçok disiplinin ilgi alanına girmektedir. Bu nedenle örgütsel bağlılık tanımlanmasında ve boyutlarında farklı açıklamalar yapıldığı göze çarpmaktadır. Örneğin; Mowday vd., (1979) örgütsel bağlılı̆̆ı belirli bir örgütle bireysel olarak kendini özleştirme derecesi ve örgüte karşı olan ilgisi olarak tanımlamaktadır. O'Reilley ve Chatman (1986) ise örgütsel bağlılığı; bireyin örgüte karşı hissettiği psikolojik bağlılık olarak ifade etmektedir. Allen ve Meyer (1990) ise örgütsel bağlılığı bireyi örgüte bağlayan psikolojik bir durum olarak tanımlamaktadır. Örgütsel bağlılık örgüt çalışan uyumuna bağlı olarak gerçekleşmektedir. Örgütsel değer ve inançlar ile bireysel değer ve inançlar arasındaki uyum düzeyi ne kadar yüksekse örgüte olan bağlılık duygusu da o oranda yüksek olmaktadır. Örgütsel bağlılığın yüksek olduğu örgütlerde, iş performansı, iş tatmini, bilgi paylaşımı, örgütsel güven, işe devam, kaynakların etkin kullanımı ve örgütsel vatandaşlık davranışı gibi konuların oranı da yüksek olmaktadır (Demirel, 2009: 116).

Literatürde örgütsel bağlılık birbirinden farklı boyutlarda açıklanmaktadır. Mayer ve Schoorman (1992) örgütsel bağlılığı değer ve devam bağlılığı olmak üzere iki boyutta açıklarken, Jaros vd., (1993) örgütsel bağlılığı; duygusal, devam ve ahlaki olmak üzere üç boyutta incelemiştir. Meyer ve Allen (1987) ise yaptığı bir çalışmada örgütsel bağlılığı; duygusal, devamlılık ve normatif bağlıık olmak üzere üç boyutta incelemiştir. Duygusal bağlılık; bireyin örgütle güçlü bir bağ kurarak kendisini tanımlaması, örgütün içinde olmaktan ve bir üyesi olmaktan mutluluk duymasıdır. Devam bağımlılığı ise bireyin örgütten ayrılmasının neden olacağı maliyetlerin farkında olması şeklinde tanımlanırken, normatif bağlılık; bireyin örgütte çalışmaya devam etmesini bir sorumluluk olarak görmesi şeklinde ifade edilmektedir (Meyer ve Allen, 1987: 200). Allen ve Meyer (1990)'e göre çalışanlar; kendileri istedikleri için güçlü duygusal bağlılıklarını, ihtiyaç duydukları için güçlü devam bağlılıklarını ve gerekli olduğunu hissettikleri için güçlü normatif bağlılıklarını sürdürmektedirler. Bu üç boyut örgütsel bağlıığın çeşitliliğinden çok birbirinden ayırt edilebilen özelliklerini oluşturmaktadır (Allen ve Meyer, 1990: 3). 


\section{3. Çalışan Memnuniyeti}

Örgütlerin başarısında çalışan memnuniyeti dolaylı da olsa etkin bir rol oynamaktadır. Çalışanların işlerinden memnuniyet duymaları, işlerine değer verdiklerini ve işlerini genel anlamıyla sevdiklerini göstermektedir. Çalışanların işlerini severek ve istedikleri için yapmaları da, örgütlere başarının kapısını açmaktadır. Çünkü örgütleri ayakta tutan en önemli etkenin, işlerini gerçek anlamda sahiplenen ve seven çalışanlar olduğu görülmektedir (Doğan ve Karataş, 2011: 2).

Çalışan memnuniyetinin 1930'lardan beri literatürde yapılmış birçok tanımı bulunmaktadır. Literatürde yapılmış tanımlarından birkaçına göre çalışan memnuniyeti şu şekilde tanımlanmaktadır. Çalışanların işine karşı göstermiş olduğu olumlu ya da olumsuz genel tutum olarak adlandırılan çalışan memnuniyeti çalışanların işine ve çevresine karşı duyduğu mutluluk duygusunu ifade etmektedir (Saager vd., 2012). Moyes vd., (2008)'e göre ise çalışan memnuniyeti bireyin işindeki pozisyonundan hoşnut olmasıdır. Davras ve Gülmez (2013)'in aktardığına göre Brief (1998) çalışan memnuniyetini, elde edilen iş deneyiminden hoşlanma veya hoşlanmama derecesinin değerlendirilerek duygusal veya bilişsel olarak ifade edildiği içsel bir durum olarak tanımlamıştır. Brief (1998), duygusallık ve bilişselliğin çalışan memnuniyetinin üzerinde mutlak bir etkisi olduğunu ve araştırmacıların duygusal boyutları ihmal ederken, sadece bilişsel boyutlara değindiğini belirtmiş̧ir (Davras ve Gülmez, 2013: 168).

Çalışan memnuniyeti, çalışanların iş ve iş çevresinde nasıl mutlu çalışanlar yaratılabilirliğinin bir ölçüsü olarak tanımlanmaktadır. Aynı zamanda çalışan memnuniyeti, bir çalışanın mutlu olup olmama durumunu ve bir çalışanın işteki ihtiyaçlarıyla arzularının çelişmesi ya da uyum içerisinde olma durumunu ifade etmektedir. Çalışan memnuniyeti örgüte ve çalışanlara birtakım faydalar sağlamaktadır. Çalışan memnuniyeti örgütsel etkinliği artırdığından dolayı etkin örgütler kurumlarında çalışan memnuniyetini teşvik etmektedirler. Çalışanların meslektaşlarıyla yarattıkları iyi iliş̧ki, yüksek ücret, iyi çalışma koşulları, eğitim ve kariyer fırsatları gibi faktörler çalışan memnuniyeti üzerinde olumlu bir etki yaratmaktadır. Artan memnuniyet sayesinde çalışanlar örgüte daha bağlı, verimli ve motivasyonu daha yüksek birer çalışan haline dönüşmektedirler (Sageer, Rafat ve Agarwal, 2012: 32).

Bu çalışmanın amacı doğrultusunda, daha önce yapılan çalışmaların sonuçlarına dayandırılarak çaIışanların iş-yaşam dengesinin, örgütsel bağlılık ve çalışan memnuniyeti üzerindeki etkileriyle ilgili hipotezler geliştirilmiştir. Geliştirilen hipotezleri üç grupta toplamak mümkündür:
$\mathrm{H}_{1}$ : İş-yaşam dengesinin örgütsel bağlılık üzerinde pozitif ve anlamlı bir etkisi vardır.

$\mathrm{H}_{2}$ : Örgütsel bağlılığın çalışan memnuniyeti üzerinde pozitif ve anlamlı bir etkisi vardır.

$\mathrm{H}_{3}$ : Iş-yaşam dengesinin çalışan memnuniyeti üzerinde pozitif ve anlamlı bir etkisi vardır.

\section{ARAŞTIRMANIN METODOLOJISi}

\subsection{Araştırmanın Amacı}

İş dünyası geliş̧ip karmaşıklaştıkça iş yaşam dengesini kurmak çalışanların en büyük sorunlarından biri haline gelmiştir. Çalışanlar günden güne zorlaşan iş koşullarına ayak uydurmakta ve bu koşullar içerisinde iş yaşam dengelerini kurmaya çalışmaktadırlar. Çalışanlar iş yaşam dengelerini kurmaya çalışırken birtakım bireysel ve çevresel faktörlerin etkisi altına girmektedirler. İş yaşam dengesiyle ilgili çalışmalara bakıldığında yurtdışı çalışmalarda yoğun olarak çalışılan bir kavram olmasına rağmen yurtiçi çalışmalarda nispeten bu konunun daha az çalışıldığı görülmektedir. Bu nedenle bu çalışmanın ilk amacı iş yaşam dengesi kavramının ne olduğu, örgütler için önemi ve çalışana etkileri ile ilgili literatürü ortaya koymaktır. Diğer taraftan iş yaşam dengesinin çalışanları etkileyen diğer iş faktörleriyle ilişkisi örgütlerin işyerinde çalışanların iş yaşamlarını daha iyi hale getirmek, örgüte olan bağlılıklarını ve dolayısıyla performanslarını arttırmak için önemlidir. Bu noktada örgütler şu soruları sormalıdır. İş yaşam dengesi çalışanın iş yaşantısını etkilemekte midir? Çalışanın memnuniyetini ve örgüte olan bağlılığını arttırmakta mıdır? İçsel pazarlama yaklaşımı çerçevesinde değerlendirildiğinde iç müşteri olarak kabul edilen çalışanların memnuniyet düzeylerinin artması, onların dış müşterilere verdikleri ürün ve hizmetlerin kalitesinin artmasına ve örgütsel amaçlara ulaşımasına katkı sağlamaktadır. Bu açıdan değerlendirildiğinde örgütlerin iş yaşam dengesi ve çalışanları etkileyen çeşitli iş faktörleri arasındaki ilişkileri araştırması ve elde edilen ilişkilere göre iş yaşam dengesini sağlama noktasında önlemler alması gerekmektedir. Bu nedenle çalışmanın ikinci bölümü iş yaşam dengesinin diğer iş faktörleri ile olan ilişkisini ortaya koymayı hedeflemektedir. Literatürde örgütsel bağlılık, çalışan memnuniyeti, iş tatmini, örgütsel performans, işten ayrılma niyeti, örgüt iklimi, örgütsel sinizm gibi birçok faktör yer almaktadır. Tüm bu faktörlerle çalışmak mümkün olmadığından iş yaşam dengesinin çalışanları etkileyen en önemli faktörlerinden biri olarak görülen örgütsel bağlılık ve iş tatmini kavramları ile olan ilişkisinin ortaya konması bu çalışmanın bir kısıtı olarak görülmektedir. 
Bu amaçla çalışmada örneklem olarak Türkiye Taş Kömürü Kurumu (TTK) seçilmiştir. Alt yapısı 1848 yılına kadar giden TTK, resmi olarak 1983 yılında devletin genel sanayi ve enerji politikalarına uygun olarak taşkömürü rezervlerinin mümkün olan en ucuz maliyetle ve çevreye en az zararı verecek şekilde değerlendirilerek ekonomiye kazandırılması amacıyla kurulmuştur. Çalışmada TTK'nın seçilmesinin nedeni kurumsal bir örgüt olmasıdır. Diğer bir nedeni ise bölgede önemli miktarda işgücünü çalıştırması ve üretimden hizmete kadar bir çok alanda faaliyet göstermesidir. Ayrıca bu örgütün çalışan performansına ilişkin araştırmaların diğer örgütlere örnek olabilme potansiyelinin yüksek olması nedeniyle bu araştırma bu örgütte yapılmıştır.

\subsection{Araştırmanın Yöntemi}

Çalışanların iş yaşam dengesinin örgütsel bağlılığa ve çalışan memnuniyetine etkisini ve örgütsel bağlılığın da çalışan memnuniyetine etkisini belirlemeye yönelik olan bu araştırma nicel bir araştırma niteliğindedir. Araştırma modeli literatürden faydalanılarak elde edilen ikincil veriler kullanılarak geliştirilmiştir. Ölçek yöntemi kullanılarak birincil veri elde edilmiş ve istatistikî analizler birincil veriler üzerinden nicel araştırma yöntemleri kullanılarak yapılmıştır. Bu nedenle bu çalışmada pozitivist yaklaşımın belirlendiği söylenebilir. Yapılan araştırma ele alınan süre açısından olguların belli bir andaki durumunu ortaya koymaya yönelik olduğu için anlık araştırmalar grubuna girmektedir. Araştırma amaç ve katkısına göre değerlendirildiğinde bu çalışma araştırma problemi ile ilgili değişkenler arası neden-sonuç ilişkisinin kurulması amacı taşıyan bir model üzerine kurulduğundan ve bu model üzerinden hipotezleri test ettiğinden dolayı araştırmanın tanımlayıcı nitelikte olduğu söylenebilir (Altunışık vd., 2005:2-13).

Ölçek uygulaması TTK genel müdürlük çalışanlarına uygulanmıştır. TTK'da yeraltı ve yerüstü çalışanlar olmak üzere toplamda Zonguldak il merkezinde yer alan bir genel müdürlükte ve çevre beldelerde yer alan bağlı 5 müdürlüklerde 11553 personel çalışmaktadır. Bu araştırma Zonguldak il merkezindeki genel müdürlük çalışanları üzerinde yapılmıştır. Genel müdürlükte 657'si memur ve 608'i işçi olmak üzere toplam 1265 personel çalışmaktadır. Ölçek uygulanmadan önce aynı kurumda 30 kişi üzerinde pilot çalışma yapılmış ve geri beslemelere göre ölçekte yer alan sorularda düzeltmeler yapılmıştır. Örnekleme yöntemi olarak kolayda örnekleme yöntemi kullanılmıştır. Ölçek uygulaması Mart-Nisan 2013 döneminde gerçekleştirilmiştir. Toplamda 304 adet kullanılabilir ölçek elde edilmiştir.
Bu araştırmada çok değişkenli istatistik tekniklerinden doğrulayıcı faktör analizi ve yapısal eşitlik modeli kullanılmıştır. Bu noktada örneklem büyüklüğü araştırmanın geçerliliği açısından önem kazanmaktadır. Faktör analizi için örnek büyüklüğü konusunda literatürde çok sayıda tartışma mevcuttur. Bunların ilki, örneklem büyüklügünün en az 50 ve mümkün ise 100'ün üzerinde olması gerektiğidir (Hair vd., 1998:98). Diğer bir görüş ise analiz edilecek ifade sayısının beş ile on katı arasında olması gerektiğidir (Albayrak, 2006:112). Kline (1998:211) doğrulayıcı faktör analizinde kullanılacak örneklem miktarının değişken sayısının en az 10 katı hatta olabilirse 20 katı olmasının uygun olacağını belirtmiştir. Bu açıklamalar doğrultusunda bu araştırmada elde edilen ölçek miktarının (304 adet) yeterli olduğu söylenebilir.

Araştırma modeli gereği olarak çalışmada iş yaşam dengesi, örgütsel bağlılık ve çalışan memnuniyeti olmak üzere literatürden faydalanılarak hazırlanmış üç ayrı ölçek kullanılmıştır. İlk olarak iş yaşam dengesi ölçeği için Netemeyer vd. (1996) tarafından geliştirilmiş olan iş aile ve aile iş çatışması ölçeklerinden faydalanılmıştır. İş yaşam dengesi ölçeği; iş yaşamı ve aile yaşamı olarak iki kısımdan oluşmaktadır. Oluşturulan ölçekte iş yaşamı için 10 madde aile yaşamı içinse 11 madde bulunmaktadır. Örgütsel bağlılık ölçeği için Meyer ve Allen (1991) tarafından geliştirilen örgütsel bağlılık ölçeği kullanılmıştır. Meyer ve Allen (1991) ölçeği araştırmalarda yaygın kullanım alanı bulmuş genel kabul görmüş bir ölçektir. Ölçek duygusal bağlılık, devamlılık bağlıı̆ı ve normatif bağlılıktan oluşmaktadır. Bu araştırmada ölçeğin normatif bağlılık kısmını oluşturan ifadelerden faydalanıımıştır. Çalışan memnuniyeti ölçeği ise literatürden faydalanılarak ve Spector (1985) tarafından geliştirilmiş ve daha sonra 1994'te ticari kullanım olmaması şartı ile araştırmacıların kullanımına sunulan Job Satisfaction Survey (JSS)'tan uyarlanmıştır. Bu ölçek orjinalde 36 sorudan oluşmaktadır. Ölçekleri oluşturan maddelerin tamamı beş'li likert tipi ölçek şeklinde sorulmuştur. Yapılan analizler sonrası iş yaşamı kısımından beş, aile yaşamı kısmından altı soru çıkarılmıştır. Örgütsel bağlılık ve çalışan memnuniyetini ölçmek için sorulan altışar sorudan ikişer tanesi analizler sonrası ölçekten çıkarılmıştır. Araştırmada kullanılan ölçeklere ait ifadeler Türkçeye orijinal dilinden araştırmacılar tarafından çevrilmiştir.

Araştırmada veri analizi için nicel araştırma yöntemlerinden yapısal eşitlik modeli (YEM) kullanılmıştır. YEM sosyal bilimlerde ve davranış bilimlerinde tamamıyla teoriye dayanarak oluşturulmuş karmaşık modellerin analizinde kullanılan bir istatistiki analiz yöntemidir. YEM, bazı fenomenlere dayanarak yapı- 
sal bir teoriyi açıklamaya (hipotez testi gibi) yönelik istatistiksel bir modeldir. Genellikle bu teori çok değişkenli yapılar üzerine gözlemler oluşturan nedensel bir süreci ortaya koyar (Bryne, 2010:3). YEM'in temel özelliği çoklu ilişkileri modellemek için yapısal eşitliklerin kullanılmasıdır. Çoklu ilişkiler etkileri ve tepkileri içeren bir yapıdır (Grace, 2006:10-11). Bu araştırmada çoklu ilişkilerin analizini içerdiği için YEM analizi kullanılmıştır.

Literatüre göre oluşturulan hipotezler kapsamında araştırmanın ölçüm modeliŞekil 2'de gösterilmektedir.

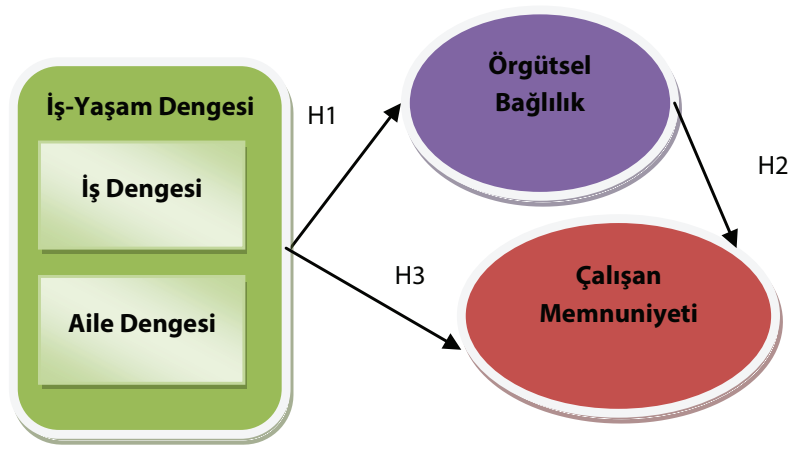

Şekil 2: Araştırmanın Ölçüm Modeli ve Hipotezleri

Araştırma modelinde iş-yaşam dengesini belirleyen iki boyut bulunmaktadır. Bunlar; iş dengesi ve aile dengesidir. Iş̧-yaşam dengesi örgütsel bağlılığı ve örgütsel bağlılık da çalışan memnuniyetini etkilemektedir. Kavramsal model temelde beş gözlenen değişkenle yapısal eşitlik modeli olarak belirlenmiştir. Her bir gözlenen değişken çalışanlara uygulanan ölçek soruları ve gizil değişkenlere ait ifadeleri içeren ölçekler yardımıyla oluşturulmuştur.

\subsection{Araştırmanın Bulguları}

Araştırma verileri SPSS 15.0 ve Amos 20 programları kullanılarak analiz edilmiştir. Araştırmaya katılan örneklemin tanımlayıcı olarak demografik özellikleri Tablo 2'de verilmektedir. Tablo 2 incelendiğinde örneklemin büyük oranda erkek, evli, 41 yaş üstü, gelir seviyesi 2001-3000 aralığında olan, daha çok yüksek okul ve üniversite mezunu kişilerden oluştuğu görülmektedir.
Tablo 2: Örneklemin Demografik Özellikleri

\begin{tabular}{|c|c|c|c|}
\hline \multicolumn{2}{|c|}{ Özellikler } & Sayı & Yüzde \\
\hline \multirow{2}{*}{ Cinsiyet } & Bayan & 45 & 14,8 \\
\hline & Bay & 259 & 85,2 \\
\hline \multirow{3}{*}{ Medeni Durum } & Evli & 234 & 77,0 \\
\hline & Bekar & 64 & 21,1 \\
\hline & Dul/Boşanmış & 6 & 2,0 \\
\hline \multirow{5}{*}{ Yaş } & 19 yaş ve altı & 1 & 3 \\
\hline & $20-26$ & 26 & 8,6 \\
\hline & $27-33$ & 52 & 17,1 \\
\hline & $34-40$ & 47 & 15,5 \\
\hline & 41 ve üstü & 178 & 58,6 \\
\hline \multirow{6}{*}{ Gelir } & Asgari Ücret & 1 & ,3 \\
\hline & $1000-2000$ & 73 & 24,0 \\
\hline & $2001-3000$ & 207 & 68,1 \\
\hline & $3001-4000$ & 16 & 5,3 \\
\hline & $4001-5000$ & 5 & 1,6 \\
\hline & 5001 ve daha fazla & 2 & , 7 \\
\hline \multirow{6}{*}{ Eğitim } & İlköğretim & 5 & 1,6 \\
\hline & Orta/Lise & 107 & 35,2 \\
\hline & Yüksekokul & 63 & 20,7 \\
\hline & Üniversite & 123 & 40,5 \\
\hline & Yüksek Lisans & 5 & 1,6 \\
\hline & Doktora & 1 & ,3 \\
\hline \multirow{4}{*}{$\begin{array}{l}\text { İşyerindeki } \\
\text { Pozisyon }\end{array}$} & Memur & 237 & 78,0 \\
\hline & Şef & 55 & 18,1 \\
\hline & Müdür Yardımcısı & 2 & , 7 \\
\hline & Müdür & 10 & 3,3 \\
\hline
\end{tabular}

Çalışan memnuniyeti, örgütsel bağlılık, iş dengesi ve aile dengesi ölçeklerine ait ortalamalar ise Tablo 3 'de verilmektedir. Ortalamaların aile dengesi haricinde ağırlıklı olarak kararsızlık noktasında olduğu görülmektedir. Bu ortalamalar incelendiğinde araştırmaya katılanların çalışan memnuniyet ortalamalarının kararsızlık ve memnuniyete yakın bir aralıkta olduğu anlaşılmaktadır. Çalışanın kurumdan memnuniyetsizliği olmasa da ortalamalar çok memnun olmadıkları yönündedir. Örgütsel bağlıık ile ilgili ortalamalar incelendiğinde çalışan memnuniyetine nispeten kuruma olan bağlıığın daha etkili olduğu görülmektedir. İş aile dengesi ile ilgili ortalamalara göre ise çalışanların aile yaşamlarındaki sıkıntılarını işlerine yansıtmadıklarını düşündükleri ancak iş yaşamındaki sıkıntıların iş yaşamındaki dengelerini etkilediği düşüncesine sahip oldukları görülmektedir. 
Tablo 3: Örneklemin Ifadelere Verdikleri Cevaplara Ilişkin Ortalamalar

\begin{tabular}{|c|c|c|c|}
\hline \multirow{5}{*}{ 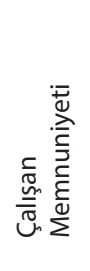 } & IFADELER & Ort. & $\begin{array}{r}\text { Standart } \\
\text { Sapma }\end{array}$ \\
\hline & Bu kurumda çalışmaktan çok memnunum (m1) & 3,67 & 1,095 \\
\hline & Bu kurumda çalışmayı çevremdekilere tavsiye ederim (m2) & 3,53 & 1,140 \\
\hline & Kendimi bu kurumun bir ferdi olarak görüyorum (m3) & 3,69 & 1,100 \\
\hline & Çalıştığım kurumda kendimi güvende hissediyorum (m6) & 3,40 & 1,133 \\
\hline \multirow{4}{*}{ 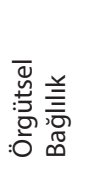 } & Şu an bu kurumdan ayrılmam, bundan sonraki hayatımda maddi zarara uğramama neden olur (b1) & 3,70 & 1,129 \\
\hline & Şu an bu kurumda kalmam, istekten ziyade gerekliliktir(b2) & 3,73 & 1,049 \\
\hline & Bu kurumdan ayrılmayı düşünmek için çok az seçim hakkına sahip olduğuma inanıyorum (b3) & 3,55 & 1,122 \\
\hline & Başka bir iş ayarlamadan bu kurumdan ayrıldığımda neler olacağı konusunda endişe hissediyorum (b5) & 3,70 & 1,098 \\
\hline \multirow{6}{*}{ 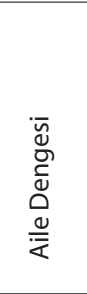 } & Evdeki sorumluluklarımdan (çocuk ve yaşıı bakımı ve ev işi) dolayı iş yaşam çatışması yaşamaktayım (a1) & 2,39 & ,986 \\
\hline & İş yaşam dengesini kuramadığımdan dolayı aile yaşamımda da kendimi mutsuz hissediyorum(a2) & 2,36 & ,984 \\
\hline & Aile yaşamından kaynaklanan stres benim işime olan konsantrasyonumu azaltmaktadır (a3) & 2,66 & 1,152 \\
\hline & Evdeki talepler nedeniyle çoğu zaman işlerimi ertelemek zorunda kalıyorum (a4) & 2,22 & 0,979 \\
\hline & Aile sorumluluklarımı yerine getirdikten sonra kendimi işte yorgun hissediyorum (a5) & 2,36 & 1,021 \\
\hline & Evdeki sorunlardan dolayı iş yerinde sıkıntı çekmekteyim (a6) & 2,25 & 0,988 \\
\hline \multirow{5}{*}{ 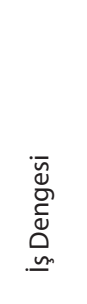 } & $\begin{array}{l}\text { Uzun çalışma saatlerinin, zorunlu fazla mesainin ve iş değişiminin iş yaşam dengemi bozduğuna } \\
\text { inanıyorum (d1) }\end{array}$ & 3,39 & 1,262 \\
\hline & $\begin{array}{l}\text { İş saatlerini aşan uzun toplantılar, bir yerden bir yere sık sık seyahat etmek iş yaşam dengemi } \\
\text { bozmaktadır (d2) }\end{array}$ & 3,23 & 1,207 \\
\hline & Yöneticilerimin ve iş arkadaşlarımın olumsuz davranışları iş yaşam dengemi bozmaktadır (d3) & 3,75 & 1,204 \\
\hline & İş paylaşımının olmaması ve eve iş götürmek zorunda kalmam iş yaşam dengemi bozmaktadır (d5) & 3,16 & 1,238 \\
\hline & İşimde artan talepler beni kişisel yaşamımda stresli bir insan haline dönüştürmektedir (d6) & 3,27 & 1,186 \\
\hline
\end{tabular}

Araştırmada kullanılan ölçeklerin güvenilirlik ve geçerliliklerini belirlemek için Cronbach Alpha katsayısı bulunarak, ölçeklere doğrulayıcı faktör analizi uygulanmıştır. Tablo 4'de araştırmada kullanılan ölçeklere ait Cronbach Alpha katsayıları, doğrulayıcı faktör analizi sonucu elde edilen faktör yükleri ve açıklanan varyansları verilmektedir. Buna göre ölçeklere ait Cronbach's Alpha katsayısı değerlerinin tamamı 0,70 değerinin üzerindedir. Bununla birlikte ölçeklerin açıklanan varyansları 0,50'den büyüktür. Bu veriler çerçevesinde ölçeklerin güvenilir ve geçerli olduğu söylenebilir.
Tablo 4: Ölçeklerin Güvenilirlik ve Geçerliliği

\begin{tabular}{|c|c|c|c|c|}
\hline & & $\begin{array}{c}\text { Cronbach's } \\
\text { Alpha }\end{array}$ & $\begin{array}{l}\text { Faktör } \\
\text { Yükleri }\end{array}$ & $\begin{array}{c}\text { Açıklanan } \\
\text { Varyans }\end{array}$ \\
\hline \multirow{5}{*}{ İş Dengesi } & d1 & \multirow{5}{*}{0,745} & 0,736 & \multirow{5}{*}{0,53} \\
\hline & d2 & & 0,832 & \\
\hline & d3 & & 0,611 & \\
\hline & d5 & & 0,563 & \\
\hline & d6 & & 0,667 & \\
\hline \multirow{6}{*}{ Aile Dengesi } & a1 & \multirow{6}{*}{0,833} & 0,605 & \multirow{6}{*}{0,54} \\
\hline & a2 & & 0,619 & \\
\hline & a3 & & 0,676 & \\
\hline & $\mathrm{a} 4$ & & 0,644 & \\
\hline & a5 & & 0,826 & \\
\hline & a6 & & 0,742 & \\
\hline \multirow{2}{*}{$\begin{array}{l}\text { İş-Yaşam } \\
\text { Dengesi }\end{array}$} & İş Dengesi & \multirow[t]{2}{*}{0,789} & 0,639 & \multirow[t]{2}{*}{0,55} \\
\hline & Aile Dengesi & & 0,328 & \\
\hline \multirow{4}{*}{$\begin{array}{l}\text { Örgütsel } \\
\text { Bağlılık }\end{array}$} & b1 & \multirow{4}{*}{0,749} & 0,566 & \multirow{4}{*}{0,57} \\
\hline & b2 & & 0,775 & \\
\hline & b3 & & 0,689 & \\
\hline & b5 & & 0,592 & \\
\hline \multirow{4}{*}{$\begin{array}{l}\text { Çalışan } \\
\text { Memnuniyeti }\end{array}$} & $\mathrm{m} 1$ & \multirow{4}{*}{0,879} & 0,647 & \multirow{4}{*}{0,73} \\
\hline & $\mathrm{m} 2$ & & 0,789 & \\
\hline & m3 & & 0,907 & \\
\hline & $\mathrm{m} 6$ & & 0,876 & \\
\hline
\end{tabular}


Doğrulayıcı faktör analizi ile ilgili ölçeklere ait uyum iyiliği indeksleri Tablo 5'de verilmektedir.YEM'de kullanılan indeksler çok çeşitli sayıdadır. Bu araştırmada genel kabul görmüş indekslerden RMSEA, NFI, GFI, CFI, AGFI ve CMIN/DF değerlerine bakılarak uyum ko- nusunda yorum yapılmıştır. RMSEA değeri 0 ile 0,05, $\mathrm{NFI}, \mathrm{GFI}, \mathrm{CFI}, \mathrm{AGFI}$ değerleri 1'e yakın olması istenir. Tablo 5'e göre araştırmada kullanılan ölçeklere ait uyum iyiliği indeksleri geçerli aralıklardadır.

Tablo 5: Araştırmanın Ölçüm Modeline İlişkin Doğrulayııı Faktör Analizlerine Ait Uyum İyiliği İndeksleri

\begin{tabular}{|l|c|c|c|c|c|c|}
\hline & RMSEA & NFI & GFI & CFI & AGFI & CMIN/DF \\
\hline İş Dengesi & 0,066 & 0,948 & 0,991 & 0,991 & 0,954 & 2,307 \\
\hline Aile Dengesi & 0,021 & 0,989 & 0,992 & 0,999 & 0,973 & 1,129 \\
\hline Örgütsel Bağlılık & 0,000 & 0,994 & 0,997 & 1,000 & 0,986 & 0,844 \\
\hline Çalışan Memnuniyeti & 0,000 & 0,998 & 0,998 & 1,000 & 0,989 & 0,660 \\
\hline
\end{tabular}

Yapısal modelin geçerliliğinin ispati için değiş- iş-yaşam dengesi ve iş dengesi arasındaki ilişkilerin kenler arası korelasyon değerlerinin incelenmesi de gerekmektedir. Değişkenler arasındaki korelasyon değerleri Tablo 6'da verilmektedir. Tablodan da görüldüğü gibi örgütsel bağlıık, çalışan memnuniyeti, anlamlı ancak düşük düzeyde olduğu, aile dengesi ile çalışan memnuniyeti arasındaki ilişkinin ise çok düşük düzeyde ve anlamsız olduğu görülmektedir.

Tablo 6. Faktörler Arası Korelasyon Değerleri

\begin{tabular}{|l|c|c|c|c|c|}
\hline & İş Tatmini & $\begin{array}{c}\text { Örgütsel } \\
\text { Bağlılık }\end{array}$ & İş-Yaşam Dengesi & Aile Dengesi & İş Dengesi \\
\hline Çalışan Memnuniyeti & 1 &, $172\left(^{* *}\right)$ &,$\left.- 245^{* *}\right)$ &,- 001 &,$- 357\left(^{* *}\right)$ \\
\hline Örgütsel Bağlılık &, $\left.172^{* *}\right)$ & 1 &, $208\left(^{* *}\right)$ &, $\left.165^{(* *}\right)$ &, $140\left(^{*}\right)$ \\
\hline İş-yaşam Dengesi &,$- 245\left(^{* *}\right)$ &, $208\left(^{* *}\right)$ & 1 &, $730\left(^{* *}\right)$ &, $734\left(^{* *}\right)$ \\
\hline Aile Dengesi &,- 001 &, $165\left(^{* *}\right)$ &, $730\left(^{* *}\right)$ & 1 &, 072 \\
\hline İş Dengesi &,$\left.- 357^{* *}\right)$ &, $140\left(^{*}\right)$ &, $734\left(^{* *}\right)$ &, 072 & 1 \\
\hline
\end{tabular}

( Not: * ${ }^{*} 0.01$ anlamlı ; 0.05 anlamlı)

Çalışanların iş-yaşam dengesinin örgütsel bağlıığa ve çalışan memnuniyetine, örgütsel bağlıığın da çalışan memnuniyetine etkisini belirlemeye yönelik oluşturulan yapısal eşitlik modelinin analiz sonuçlarına ait uyum iyiliği indeksleri Tablo 7'de yer almakta- dır. Buna göre; elde edilen bulguların, iyi uyum iyiliği ve kabul edilir değer aralığında olduğu dolayısıyla yapısal eşitlik modelinin kabul edilebilir bir seviyede olduğu söylenebilir (Schermelleh-Engel vd., 2003:52; Kline, 1998:128).

Tablo 7: Yapısal Modele Ait Uyum İyiliği

\begin{tabular}{|c|c|c|c|c|c|c|}
\hline & RMSEA & NFI & GFI & CFI & AGFI & CMIN/DF \\
\hline MODEL & 0,041 & 0,907 & 0,934 & 0,967 & 0,911 & 1,500 \\
\hline
\end{tabular}

Yapısal modelde standardize edilmemiş regresyon katsayılarının verildiği Tablo 8'de modelde kullanılan değişkenlerin ve değişkenler arasındaki ilişkilerin iş-yaşam dengesi ile çalışan memnuniyeti hariç tamamının anlamlı olduğu görülmektedir. 
Tablo 8: Yapısal Modele Ait Standardize Edilmemiş Regresyon Katsayıları

\begin{tabular}{|c|c|c|c|c|c|c|}
\hline Bağımsız Değişkenler & & Bağımlı Değişkenler & Tahmin & Standart Hata & $\mathrm{t}$ & $P$ \\
\hline Örgütsel bağlılık & $<--$ & İş-Yaşam Dengesi & ,916 & 388 & 2,362 & 0,018 \\
\hline İş dengesi & $<--$ & İş-Yaşam Dengesi & 1,000 & & & \\
\hline Aile dengesi & $<---$ & İş-Yaşam Dengesi &, 433 & 173 & 2,504 & 0,012 \\
\hline Çalışan memnuniyeti & $<--$ & Örgütsel bağlılık & 289 & ,138 & 2,091 & 0,036 \\
\hline Çalışan memnuniyeti & $<--$ & İş-Yaşam Dengesi &,- 321 & 288 & $-1,115$ & 0,265 \\
\hline d6 & $<--$ & İş dengesi & 1,000 & & & \\
\hline $\mathrm{d} 5$ & $<--$ & İş dengesi & 1,003 & ,126 & 7,935 & 0,00 \\
\hline d3 & $<--$ & İş dengesi & 1,071 & 144 & 7,443 & 0,00 \\
\hline$d 2$ & $<--$ & İş dengesi & 1,441 & 179 & 8,032 & 0,00 \\
\hline d1 & $<--$ & İş dengesi & 1,345 & 167 & 8,042 & 0,00 \\
\hline a1 & $<--$ & Aile dengesi & 1,000 & & & \\
\hline a2 & $<--$ & Aile dengesi & 1,028 & 108 & 9,478 & 0,00 \\
\hline a3 & $<--$ & Aile dengesi & 1,334 & 150 & 8,863 & 0,00 \\
\hline a4 & $<--$ & Aile dengesi & 1,054 & ,116 & 9,088 & 0,00 \\
\hline a5 & $<---$ & Aile dengesi & 1,420 & 143 & 9,934 & 0,00 \\
\hline a6 & $<--$ & Aile dengesi & 1,224 & 122 & 10,013 & 0,00 \\
\hline m6 & $<--$ & Çalışan memnuniyeti & 1,000 & & & \\
\hline m3 & $<--$ & Çalışan memnuniyeti & 1,183 & 101 & 11,686 & 0,00 \\
\hline $\mathrm{m} 2$ & $<--$ & Çalışan memnuniyeti & 1,403 & 110 & 12,799 & 0,00 \\
\hline $\mathrm{m} 1$ & $<--$ & Çalışan memnuniyeti & 1,305 & 104 & 12,594 & 0,00 \\
\hline b5 & $<--$ & Örgütsel bağlılık & 940 & ,125 & 7,541 & 0,00 \\
\hline b3 & $<--$ & Örgütsel bağlılık & 1,154 & 157 & 7,373 & 0,00 \\
\hline b2 & $<--$ & Örgütsel bağlılık &, 950 & 140 & 6,810 & 0,00 \\
\hline b1 & $<---$ & Örgütsel bağlılık & 1,000 & & & \\
\hline
\end{tabular}

Yapısal modele ait standardize edilmiş regresyon memnuniyeti üzerinde anlamlı bir etkisinin olmadığı, katsayıları Tablo 9'da yer almaktadır. Standardize edil- örgütsel bağlılığın ise çalışan memnuniyetini etkiledimemiş regresyon katsayılarında görüldüğü üzere iş ği sonucuna varılmıştır. yaşam dengesinin örgütsel bağlılığı etkilediği, çalışan 
Tablo 9: Yapısal Modele Ait Standardize Edilmiş Regresyon Katsayıları

\begin{tabular}{|c|c|c|c|}
\hline \multicolumn{3}{|l|}{ Değişkenler } & \multirow{2}{*}{$\frac{\text { Tahmin }}{\text {,583 }}$} \\
\hline Örgütsel bağlılık & $<---$ & İş-Yaşam Dengesi & \\
\hline İş dengesi & $<---$ & İş-Yaşam Dengesi & 647 \\
\hline Aile dengesi & $<--$ & İş-Yaşam Dengesi & ,325 \\
\hline Çalışan memnuniyeti & $<---$ & Örgütsel bağlılık & 276 \\
\hline Çalışan memnuniyeti & $<---$ & İş-Yaşam Dengesi &,- 195 \\
\hline d6 & $<---$ & İş Dengesi & ,583 \\
\hline d5 & $<---$ & İş Dengesi & ,559 \\
\hline d3 & $<--$ & İş Dengesi & 615 \\
\hline$d 2$ & $<--$ & İş Dengesi & 824 \\
\hline d1 & $<---$ & İş Dengesi & ,736 \\
\hline a1 & $<---$ & Aile dengesi & 603 \\
\hline a2 & $<--$ & Aile dengesi & 619 \\
\hline a3 & $<--$ & Aile dengesi & 688 \\
\hline a4 & $<---$ & Aile dengesi & 641 \\
\hline a5 & $<--$ & Aile dengesi & 827 \\
\hline a6 & $<--$ & Aile dengesi & ,737 \\
\hline $\mathrm{m} 6$ & $<--$ & Çalışan memnuniyeti & 649 \\
\hline m3 & $<---$ & Çalışan memnuniyeti & 790 \\
\hline $\mathrm{m} 2$ & $<--$ & Çalışan memnuniyeti & ,905 \\
\hline $\mathrm{m} 1$ & $<--$ & Çalışan memnuniyeti & 877 \\
\hline b5 & $<--$ & Örgütsel bağlılık & 600 \\
\hline b3 & $<--$ & Örgütsel bağlılık & ,721 \\
\hline b2 & $<---$ & Örgütsel bağlıık & 635 \\
\hline b1 & $<--$ & Örgütsel bağlılık & 621 \\
\hline
\end{tabular}

Yapısal eşitlik modeli sonuçlarına göre; iş yaşam anlamlı bir etkisinin bulunmadığı tespit edilmiştir. dengesinin örgütsel bağ|ıı̆̆ı, örgütsel bağlıı̆̆ın da Yukarıdaki regresyon sonuçlarına göre oluşturulan çalışanların memnuniyetini anlamlı olarak etkilediği araştırmaya ilişkin değişkenlere ait ilişkiler Şekil 3'de ancak iş-yaşam dengesinin çalışan memnuniyetine verilmektedir.

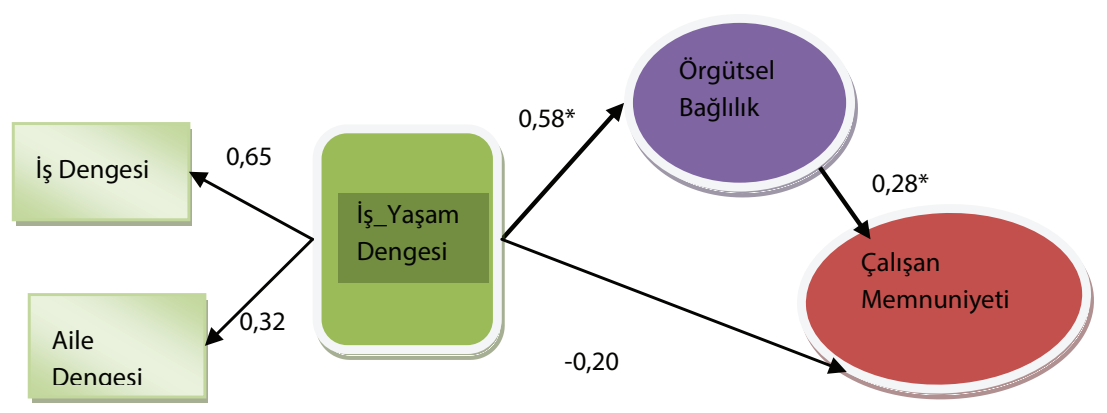

Şekil 3: Araştırmanın Yapısal Modeli ve Elde Edilen Sonuçlar

( Not: * 0.05 anlamlı) 
Sonuç olarak; iş-yaşam dengesinin örgütsel bağlılık üzerinde anlamlı ve pozitif etkisinin olduğunu ifade eden $\mathrm{H}_{1}$ hipotezi ile örgütsel bağlılığın çalışan memnuniyeti üzerinde pozitif ve anlamlı etkisinin bulunduğunu ifade eden $\mathrm{H}_{2}$ hipotezi kabul edilmiştir. Buna karşın iş-yaşam dengesinin çalışan memnuniyeti üzerinde pozitif ve anlamlı etkisi olduğunu ifade eden $\mathrm{H}_{3}$ hipotezi red edilmiştir.

Tablo 9: Araştırma Hipotezlerinin Değerlendirilmesi

\begin{tabular}{|l|l|l|l|l|l|}
\hline Hipotez & Bağımsız Değişken $\rightarrow$ Bağımlı Değişken & $\beta$ katsayısı & t değeri & $p$ & Sonuç \\
\hline $\mathrm{H}_{1}$ & İş-Yaşam Dengesi $\rightarrow$ Örgütsel Bağlıık & 0,583 & 2,362 & 0,018 & KABUL \\
\hline $\mathrm{H}_{2}$ & Örgütsel Bağlıık $\rightarrow$ Çalışan Memnuniyeti & 0,276 & 2,504 & 0,036 & KABUL \\
\hline $\mathrm{H}_{3}$ & İş-Yaşam Dengesi $\rightarrow \quad$ Çalışan Memnuniyeti & $-0,195$ & $-1,115$ & 0,265 & RED \\
\hline
\end{tabular}

\section{SONUÇ VE DEĞERLENDIRME}

İş yaşam dengesi örgütler için hayati bir önem taşımaktadır. İş yaşam dengesi ile ilgili problemleri olan örgütlerde; devam sorunları, isteksizlik, iş esnasında boşa zaman harcama gibi çalışanların performansını etkileyen ve örgütlerde kayıplara neden olan çıktılar görülebilmektedir. Diğer taraftan bu dengesizlik çeşitli iş çıktılarını etkileyerek gerek örgütlere gerekse çalışanlara olumsuz yansımaktadır. Bu çalışma ile iş yaşam dengesinin örgütsel bağlılık ve çalışan memnuniyeti ile olan iliş̧kisi ve etkileri incelenmiştir. Örgütsel bağlılık, çalışanları işyerinde motive eden performanslarını etkileyen önemli bir faktördür. Ayrıca çalışan memnuniyeti, verimliliği ve müşteri memnuniyetini de etkilemektedir. Bu iki faktör çalışanların performanslarını ve motivasyonlarını arttırmada önemli iki faktör olarak değerlendirilmektedir.

Bu çalışma ile Zonguldak'ta faaliyet gösteren Türkiye Taş Kömürü Kurumu çalışanları üzerine uygulamalı bir araştırma yapılmış ve iş yaşam dengesinin örgütsel bağlılık ve çalışan memnuniyeti üzerindeki etkisi yapısal eşitlik modeli yardımıyla açıklanmaya çalışılmıştır. Yapılan araştırma ile örgütlerin insan kaynağına ilişkin bulgular elde edilmiştir. Ayrıca literatür araştırmaları sonucunda bu çalışma iş yaşam dengesi ile örgütsel bağlılık ve çalışan memnuniyeti ilişkilerini birarada inceleyen Türkiye'de ve TTK'da yapılmış ilk çalışmadır. Literatür incelendiğinde yaygın olarak iş ve aile çatışması incelenmiş olmakla birlikte bu çatışmaların iş çıktıları ile ilgili ilişkilerinin yeraldığı çalışmaların sınırlı kaldığı görülmektedir.

Araştırma bulguları ise şu şekildedir. Yapılan korelasyon analizi sonuçlarına göre; örgütsel bağlılık, çalışan memnuniyeti, iş yaşam dengesi ve iş dengesi arasındaki ilişkilerin anlamlı ancak düşük düzeyde, aile dengesi ile çalışan memnuniyeti arasındaki ilişkinin ise çok düşük düzeyde ve anlamsız olduğu belirlenmiştir. Araştırma modeline göre iş yaşam dengesinin örgütsel bağlılığı, örgütsel bağlılığın ise çalışanların memnuniyetini anlamlı olarak etkilediği ancak iş yaşam dengesinin çalışan memnuniyetine anlamlı bir etkisinin olmadığı tespit edilmiştir. Sonuç olarak; iş yaşam dengesinin örgütsel bağlılık üzerinde anlamlı ve pozitif etkisinin olduğunu ifade eden $\mathrm{H}_{1}$ hipotezi ile örgütsel bağlıı̆ın çalışan memnuniyeti üzerinde pozitif ve anlamlı etkisinin olduğunu ifade eden $\mathrm{H}_{2}$ hipotezi kabul edilmiştir. Buna karşın iş yaşam dengesinin çalışan memnuniyeti üzerinde pozitif ve anlamlı etkisi olduğunu ifade eden $\mathrm{H}_{3}$ hipotezi ise red edilmiştir. Elde edilen bu bulgular benzer çalışmalarla desteklenmiştir.

Bu çalışma bulgularını destekler nitelikteki çalışmalardan biri olan Malone ve Issa (2013)'nın çalışması iş yaşam dengesinin en yüksek etkiyi örgütsel bağlılık üzerinde gösterdiğini tespit etmiştir. Diğer bir çalışma Gao vd. (2013) duygusal zekayı moderatör olarak kullanarak iş aile çatışması ile iş tatmini arasındaki ilişkiyi araştırmış ve iş aile çatışmasının iş tatminini olumsuz etkilediğini ve duygusal zekanın bu etkiyi zayıflattığı sonucuna ulaşmışlardır. Sakthivel ve Jayakrishnan (2012) ise iş yaşam dengesinin örgütsel bağlılığı etkilediğini ve iş yaşam dengesi ile örgütsel bağlılık arasında pozitif yönlü bir ilişki olduğunu belirlemişlerdir. Azim vd. (2012) çalışmalarında iş yaşam dengesinin işteki otonomi, iş aile psikolojik sözleşmesi ve örgütsel bağlılık ile ilişkili olduğunu ve iş aile psikolojik sözleşmesinin de örgütsel bağlılık ile ilişkisi olduğunu tespit etmişlerdir. Benligiray ve Sönmez (2012) doktor ve hemşireler üzerine yaptıkları bir çalışmada örgütsel bağlılık ile iş aile çatışması arasında zayıf ve pozitif yönde bir iliş̧ki bulmuşlardır. Bu çalışmada doktor ve hemşirelerin örgütsel bağlılığı arttıkça iş aile çatışmalarının da arttığı ifade edilmektedir. Bu nedenle çalışanların iş ve aile dengelerini kurmalarının örgütsel bağlılığı geliştireceği sonucuna ulaşıımıştır. Noor (2011)'un araştırmaları ise iş memnuniyeti ile örgütsel bağlılığın iş yaşam dengesi ve işten ayrılma niyetine kısmen aracılık etkisinin bulunduğunu göstermektedir. O'Neill vd. (2009) ise otel çalışanları üzerinde yaptıkları bir çalışmada iş-aile iklimi ile hem örgütsel bağlılık hem de işten ayrılma niyeti arasında önemli bir birliktelik olduğunu göstermişlerdir. Araştırma sonucunda çalışanların iş aile iklimi için yönetimsel des- 
tek verilmesinin önemli olduğu ve üst düzey yöneticilerin kendi iş aile şartları ile çalışanlarının iş çıktıları arasında bir ilişki olduğu saptanmıştır. Çalışmalardan da anlaşıldığı üzere iş yaşam dengesi ile örgütsel bağlılık arasında bir ilişki bulunmaktadır. İ̧̧ yaşam dengesi arttıkça örgütsel bağlılık artmaktadır. Bu nedenle örgütler çalışanların iş yaşam dengesini kurmalarına yardımcı olacak uygulamalarla çalışanlarını desteklemelidir. Aile hayatının işe taşınmaması ve iş stresinin de aileye yansıtılmaması için çalışanların iş yükleri ile ilgili dağımlara dikkat edilmeli, aşırı iş yükü engellenmeli ve işyerinde işte yaşadıkları stresi azaltıcı etkinlikerin düzenlenmesi gerekmektedir.

Araştırmanın ikinci hipotezi olan çalışan memnuniyetinin örgütsel bağlılığa etkisi anlamlı çıkmıştır. Bu bulguyu destekleyici olarak literatürde çok sayıda çalışmadan bahsetmek mümkündür. Angle ve Perry (1981), Hunt vd. (1985) gibi eski çalışmalarda örgütsel bağlılık ile iş tatmini arasında güçlü ilişkiler tesbit edilmiştir. Daha güncel çalışmalarda da bu ilişkinin varlığı desteklenmektedir. Martensen ve Gronholdt (2006) çalışanların iş tatmini ve sadakatinin örgütlerin algılanan firma değerine katkısı olduğunu ifade etmektedirler. Çalışmada iş tatmininin çalışan sadakatini arttırdığı tesbit edilmiştir. Lumley vd. (2011) örgütsel bağlııkla iş tatmini arasında anlamlı bir ilişki bulmuştur. Bu sonuca göre memnun çalışan işyerine daha çok bağlanmakta ve sorumluluk hissetmektedir. Memnuniyetin artması örgüte olan bağlılığı artırmaktadır. Bağlı çalışan işyerinde daha mutlu ve daha az stresle çalışacak ve bu durum iş ve aile dengesine yansıyacaktır.

Bu çalışmada iş yaşam dengesinin çalışan memnuniyeti üzerine herhangi bir etkisi bulunamamıştır. Literatür incelendiğinde bu durumun aksine bulgular olduğu görülmektedir. Bunlardan biri Rani vd. (2011) tarafından yapılmıştır. Bu çalışmada çalışan memnuniyeti ile iş-yaşam dengesi arasındaki ilişki araştırılmış ve çalışanların işteki görevleri ile memnuniyetleri arasında yüksek düzeyde bir ilişki olduğu bu ilişkinin ise iş yaşam dengesinin aracı bir rolü olduğu belirlenmiştir. Saif vd. (2011) ise yaptıkları bir çalışmada iş yaşam dengesinin çalışanın iş memnuniyeti üzerinde pozitif ve anlamlı bir etkisi olduğunu belirlemişlerdir.
Beauregard ve Henry (2009) iş-aile dengesi ve örgütsel performans arasındaki ilişki üzerine yaptıkları çaış̧malarında iş aile çatışmasının örgütsel performansı etkilediğini, bu etkinin işin derecesi, yönetim desteği gibi faktörlerce modere edildiğini ifade etmişlerdir. Bu çalışmada iş yaşam dengesinin çalışan memnuniyeti üzerinde anlamlı bir etkisinin olmayışının çok sayıda sebebi olabilir. Temel sebeplerinden biri bu örneklemde iş dengesi ve aile dengesinden oluşan iş aile dengesi ile çalışan memnuniyeti ortalamaları arasında ayrıt edici bir farklııı̆ın olmamasından kaynaklandığı düşünülebilir. Yani gerek iş aile dengesi gerekse çalışan memnuniyeti ortalamaları birbirine yakındır. Diğer taraftan araştırmanın kısıtı olarak değerlendirilebilecek diğer değişkenlerin etkilerinin modelde yer almaması bu ilişkiyi açıklamada zayıflı̆a sebep olabilir.

Bu araştırmada çeşitli kısıtlar bulunmaktadır. Araştırmanın öncelikli kısıtı zaman ve maliyet nedeniyle araştırmada evrenin tamamına ulaşılamamış olmasıdır. Diğer taraftan çalışma tesadüfî örnekleme dayalı olmadığından genelleme yapılamamaktadır. Araştırmanın diğer kısıtlarından biri araştırmanın tek seferde ve anlık olarak elde edilmiş birincil verilere dayandırılarak yapılmış olmasıdır. Diğer bir kısıt araştırmanın tek bir kurum üzerinden yürütülmüş olmasıdır. Ayrıca bu kurum kamu kurumudur. İ̧ yaşam dengesi ile ilgili sorun yaşayan çalışanların oluşturduğu örgütlerde en olumsuz etki personel devir hızının artmasıdır. Kamu kurumlarında personel devir hızı düşüktür. Bu çalışma kurumsal özel bir örgütte uygulanarak sonuçların karşılaştırılması bu alanda çalışacak araştırmacılar için yeni çalışma konusu olabilir. Yapılan çalışmalardan da görüldüğü üzere, iş yaşam dengesinin; örgütsel bağlılığı ve çalışan memnuniyetini etkilemesi nedeniyle ele alınması gereken önemli bir konu olduğu görülmektedir. Konu ile ilgili gelecekte yapılacak çalışmalar sayesinde iş yaşam dengesini etkilediği düşünülen daha fazla değişkenin iş yaşam dengesiyle olan ilişkisi incelenebilecektir. Dolayısıyla yapılacak olan bu çalışmalardan elde edilen bulgularla örgütlerin insan kaynağına yönelik yeni politikalar üretilebilecektir. 


\section{KAYNAKLAR}

Albayrak, A.S. (2006) Uygulamalı Çok Değişkenli İstatistik Teknikleri, Ankara, 1. Baskı, Asil Yayın Dağıtım.

Allen, N.J. ve Meyer, J.P. (1990) “The Measurement and Antecedents of Affective, Continuance and Normative Commitment to The Organization" Journal of Occupational Psychology, 63: 1-18.

Altunışık, R., Çoşkun, R., Bayraktaroğlu, S. ve Yıldırım, E. (2005) Sosyal Bilimlerde Araştırma Yöntemleri, Sakarya, 4. Baskı, Sakarya Kitapevi.

Angle, H.L. ve Perry, J. L. (1981) "An Empirical Assessment of Organisational Commitment and Organisational Effectiveness" Administrative Science Quarterly, 26:1-14.

Azim, A.M.M., Ahmad, A., Omar, Z. ve Silong, A.D. (2012) "Work-Familiy Contract, Job Autonomy and Organizational Commitment" American Journal of Applied Sciences, 9(5): 740-747.

Beauregard, T.A. ve Henry, L.C. (2009) "Making the Link between Work-life Balance Practices and Organizational Performance" Human Resource Management Review, 19: 9-22.

Benligiray, S. ve Sönmez, H. (2012) "Analysis of Organizational Commitment and Work-family Conflict in View of Doctors and Nurses" The International Journal of Human Resource Management, 23(18): 3890-3905.

Byrne, B.M. (2010) Structural Equation Modeling with Amos, New York, Second Edition, Rotledge Taylor\&Francis Group.

Cieri, H.D., Holmes, B., Abbott, J. ve Pettit, T. (2002) Work/Life Balance Strategies: Progress and Problems in Australian Organizations, USA, Monash University Working Paper Series.

Clutterbuck, D. (2003) Managing Work-Life Balance: A Guide for HR in Achieving Organisational and Individual Change, London, CIPD Publishing.

Darcy, C., McCarthy, A., Hill, J. ve Grady, G. (2012) "Work-Life Balance: One Size Fits All? An Exploratory Analysis of The Differential Effects of Career Stage" European Management Journal, 30: 111-120.

Davras, Ö. ve Gülmez, M. (2013) "Otel İşletmelerinde Çalışan Memnuniyetine Etki Eden Faktörler: Kemer, Lara, Belek, Side, Alanya Bölgelerinde Bir Çalışma” Anatolia: Turizm Araştırmaları Dergisi, 24(2): 167-184.

Demirel, Y. (2009) "Örgütsel Bağlllık ve Üretkenlik Karşıtı Davranışlar Arasındaki İlişkiye Kavramsal Yaklaşım" İstanbul Ticaret Üniversitesi Sosyal Bilimler Dergisi, 8(15): 115-132.
Doğan, S. ve Karataş, A. (2011) "Örgütsel Etiğin Çalışan Memnuniyetine Etkisi Üzerine Bir Araştırma” Erciyes Üniversitesi İktisadi ve İdari Bilimler Fakültesi Dergisi, 37: 1-40.

Doğrul, B.Ş. ve Tekeli, S. (2010) "i̧̇s-Yaşam Dengesinin Sağlanmasinda Esnek Çalışma” Sosyal ve Beşeri Bilimler Dergisi, 2(2): 11-18.

Doherty, L. ve Manfredi, S. (2006) "Action Research to Develop Work-Life Balance in a UK University" Women In Management Review, 21(3): 241-259.

Gao, Y., Shi, J., Niu, Q. ve Wang, L. (2013) "WorkFamily Conflict and Job Satisfaction: Emotional Intelligence as a Moderator" Stress and Health, 29: 222-228.

Grace, J.B. (2006) Structural Equation Modelling and Natural Systems, New York, Cambridge University Press.

Greenhaus, J.H., Collins, K.M. ve Shaw, J. D. (2003) "The Relation Between Work-Family Balance and Quality of Life" Journal of Vocational Behavior, 63: 510-531.

Gordon, J.R., Whelan-Berry, S.K. ve Hamilton, E. A. (2007) "The Relationship among Work-Family Conflict and Enhancement, Organizational Work-Family Culture, and Work Outcomes for Older Working Women" Journal of Occupational Health Psychology, 12(4): 350-364.

Guest, D.E. (2001) Perspectives on the Study of Work-Life Balance, A Discussion Papared for The 2001 ENOP Symposium, Paris, March 29-31.

Hair, J.F., Anderson, R.E., Tatham, R. L. ve Black, W.C. (1998) Multivariate Data Analysis, New Jersey, Fifth Edition, Prentice-Hall, Inc.

Hennessy, K.D. (2007) “Work-Family Balance: An Exploration of Conflict and Enrichment for Women in a Traditional Occupation" Unpublished Ph.D. Dissertations, USA, University of Maryland.

Hildebrandt, E. (2006) "Balance Between Work and Life-New Corporate Impositions Through Flexible Working Time or Opportunity for Time Sovereignty?" European Societies, 8(2): 251-271.

Hunt, S.D., Wood, V.R. ve Chonko, L.B. (1985) "Organisational Commitment and Marketing" Journal of Marketing, 49:112-126.

Jaros, S.J., Jermier, J.M., Koehler, J.W. ve Sincich, T. (1993) "Effects of Continuance, Affective, and Moral Commitment on the Withdrawal Process: An Evaluation of Eight Structural Equation Models" Academy of Management Journal, 36: 951-995.

Kapız, S.Ö. (2002) "iş-Aile Yaşamı Dengesi ve Dengeye Yönelik Yeni Bir Yaklaşım: Sinır Teorisi” Dokuz Eylül Üniversitesi Sosyal Bilimler Enstitüsü Dergisi, 4(3):139-153. 
Khallash, S. ve Kruse, M. (2012) "The Future of Work and Work-Life Balance 2025" Welfare Futures, 44: 678-686.

Kılı̧̧, R. ve Sakall, S. Ö. (2013) "Örgütlerde Stres Kaynaklarmın Çalışanların İs-Aile Çatı̧̧ması Üzerine Etkisi" Uşak Üniversitesi Sosyal Bilimler Dergisi, 6(3):208-237.

Kline, R.B. (1998) Principles and Practice of Structural Equation Modeling, New York, Guildford Press.

Küçükusta, D. (2007) "Konaklama İşletmelerinde İş-Yaşam Dengesi Sorunları ve Çözüme Yönelik Yaklaşımlar" Dokuz Eylül Üniversitesi Sosyal Bilimler Enstitüsü Dergisi, 9(3): 243-268.

Lockwood, R.N. (2003) Work/Life Balance Challenges and Solutions, USA, Society For Human Resource Management.

Lumley E.J., Coetzee, M., Tladinyane, R. ve Ferreira, N. (2011) "Exploring The Job Satisfaction and Organisational Commitment of Employees in The Information Technology Environment" Southern African Business Review, 15(1):100-118.

Malone, E.K. ve Issa, R.R.A. (2013) "Work-Life Balance and Organizational Commitment of Women in the U.S. Construction Industry" 139(2): 87-98.

Manfredi, S. ve Holliday, M. (2004) "Work-Life Balance, Great Britain” The Centre for Diversity Policy Research.

Martensen, A. ve Gronholdt, L. (2006) "Internal Marketing: A Study of Employee Loyality, Its Determinants and Consequences" Innovative Marketing, 2(4): 92-116.

Mauno, S. ve Rantanen, M. (2012) "Contextual and Dispositional Coping Resources as Predictors of Workfamily Conflict and Enrichment: Which of These Resources or their Combinations are the Most Beneficial?" Journal of Family and Economic, 34(1): 87-104.

Maxwell, G. A. (2005) "Checks and Balances: The Role of Managers in Work-Life Balance Policies and Practices" Journal of Retailing and Consumer Services, 12:179-189.

Mayer, R. C. ve Schoorman, F. D. (1992) "Predicting Participation and Production Outcomes Through a TwoDimensional Model of Organizational Commitment" Academy of Management Journal, 35: 671-84.

McGraw, P. ve Heidtman, D. (2009) "Work Life Balance in Australian Legal Firms" IJES, 17(2): 1-33.

Meyer, J.P. ve Allen, N.J. (1987) "A Longitudinal Analysis of The Early Development and Consequences of Organizational Commitment" Canadian Journal of Behavioral Science, 19(2): 199-215.

Meyer, J. P. ve Allen, N. J. (1991) "A Three-Compo- nent Conceptualization of Organizational Commitment" Human Resource Management Review, 1: 61-89.

Morgan, L. (2009) "The Impact of Work-Life Balance and Family-Friendly Human Resource Policies on Employees' Job Satisfaction" Unpublished PhD. Dissertations, USA, Nova Southeastern University.

Mowday, R.T., Steers, R.M. ve Porter, L.W. (1979) "The Measurement of Organizational Commitment" Journal of Vocational Behavior, 14(2): 224-247.

Moyes, G.D., Shao, L.P. ve Newsome, M. (2008) "Comparative Analysis of Employee Job Satisfaction in the Accounting Profession" Journal of Business \& Economics Research, 6(2): 65-81.

Naithani, P. (2010) "Overview of Work-Life Balance Discourse and Its Relevance in Current Economic Scenario" Asian Social Science, 6(6):148-155.

Narayanan, A.G.V ve Narayanan, L.R. (2012) "An Empirical Study on Factors Affecting Work-Life Balance of IT Professionals" European Journal of Social Sciences, 31(3): 302-313.

Noor, K.M. (2011) "Work-Life Balance and Intention to Leave among Academics in Malaysian Public Higher Education Institutions" International Journal of Business and Social Science, 2(11): 240-248.

O’Neill, J.W., Harrison, M.M., Cleveland, J., Almeida, D., Stawski, R. ve Crouter, A.C. (2009) "Work-family Climate, Organizational Commitment, and Turnover: Multilevel Contagion Effects of Leaders" Journal of Vocational Behaviour, 74:18-29.

O’Reilly, C.A. ve Chatman, J. (1986) “Organizational Commitment and Psychological Attachment: The Effects of Compliance, Identification, and Internalization on Prosocial Behavior" Journal of Applied Psychology, 71:492499.

Palmeri, S. (2013) "Surviving a Reduction in Force: The impact of Flexible Work Arrangements on Employee Job Satisfaction and Work/life Balance Following the 2008 Recession" Unpublished Ph.D. Dissertations, USA, Capella University.

Rani, S.K. (2011) "Work/Life Balance Reflection on Employee Satisfaction" Serbian Journal of Management, 6(1): 85-96.

Sageer, A., Rafat, S. ve Agarwal, P. (2012) "Identification of Variables Affecting Employee Satisfaction and Their Impact on the Organization" IOSR Journal of Business and Management, 5(1): 32-39.

Saif, M.I., Malik, M.I. ve Awan, M.Z. (2011) "Employee Work Satisfaction and Work - Life Balance: A Pakistani Perspective" Interdisiplinary Journal of Contemporary Research In Business, 3(5): 606-617. 
Sakthivel, D. ve Jayakrishnan, J. (2012) "Work Life Balance and Organizational Commitment for Nurses" Asian Journal of Business and Management Sciences, 2(5): 1-6.

Saltzstein, A.L., Ting, Y. ve Saltzstein, G.H. (2001) "Work-Family Balance and Job Satisfaction: The Impact of Family-Friendly Policies on Attitudes of Federal Government Employees" Public Administration Review, 61:452-467.

Schermelleh-Engel, K., Moosbrugger, H. ve Müller, H. (2003) "Evaluating the Fit of Structural Equation Models: Tests of Significance and Descriptive Goodnessof-Fit Measures" Methods of Psychological Research, 8(2): 23-74.

Spector, P. (1985) "Measurement of Human Service Staff Satisfaction: Development of The Job Satisfaction Survey" American Journal of Community Psychology, 12(6): 639-713.

Susi, S. ve Jawaharrani, K. (2011) "Work-Life Balance: The Key Driver of Employee Engagement" Asian Journal of Management Research, 2(1): 474-483.

Tariq, A., Aslam, H. D., Siddique, A. ve Tanveer, A. (2012) "Work-Life Balance as a Best Practice Model of Human Resource Management: A Win-Win Situational
Tool fort he Employees and Organizations" Mediterranean Journal of Social Sciences, 3(1): 577-585.

Thulasimani, K. K., Duraisamy, M ve Rathinasabapathi, S. S. (2010) "A Study on Work Life Balance Amongst Managers of Garment Units in Tamilnadu State, India" International Journal of Human Sciences, 7(2): 445-460.

Tucholka, A. ve Weese, S. (2007) Work-Life Balance and Health Care Benefits-Essential Forms of Modern Life-Cycle Benefits, Germany, GRIN Verlag.

Virick, M., Lilly, J.D. ve Casper, W.J. (2007) “Doing more with less: An Analysis of Work Life Balance Among Layoff Survivors" Career Development International, 12(5): 463-480.

Wirtz, A., Nachreiner, F. ve Rolfes, K. (2011) "Working on Sundays-Effects on Safety, Health, and Work-life Balance" Chronobiology International, 28(4): 361-370.

Wong, S. C-K. ve Ko, A. (2009) "Exploratory Study of Understanding Hotel Employees' Perception on Work-Life Balance Issues" International Journal of Hospitality Management, 28: 195-203. 
